\title{
A Comparative Study of Student Unions Inside and Outside Mainland China
}

\author{
Xiangli $\mathrm{Ou}^{1}$, Kang $\mathrm{Gao}^{1}$ \& Congcong $\mathrm{Xu}^{2}$ \\ ${ }^{1}$ Office of Student Affairs, Jinan University, Guangzhou, China \\ ${ }^{2}$ Party Committee Office, South China Agricultural University, Guangzhou, China \\ Correspondence: Xiangli Ou, Office of Student Affairs, Jinan University, Guangzhou, China. E-mail: \\ 380439506@qq.com.
}

Received: December 17, 2017

doi:10.5539/ass.v14n7p99

\author{
Accepted: December 26, 2017 \\ Online Published: June 22, 2018 \\ URL: https://doi.org/10.5539/ass.v14n7p99
}

\begin{abstract}
With higher education entering a new normal status in China, student unions in higher education face new opportunities and challenges. To overcome these challenges it is necessary to learn from the successful experiences of student organizations inside and outside mainland China to create a reference for improving the creation process, organization and administration of student unions. This article presents an analysis and contrast of different organizational aspects of student unions in mainland China, Hong Kong, Macau and Taiwan (HMT), and the United States such as their current development stages, creation and authorization process, structure, types of activities, sources of economic support and internal administration. Based on the differences, we propose to strengthen the administration of student unions, improve regulations, expand the sources of economic support, innovate activity forms, and promote the integration of student organizations and society with an aim of fostering a culture of inclusion, and ensuring a sound and sustainable development of student unions.
\end{abstract}

Keywords: higher institutions inside and outside mainland China, student union, organization contrast

The student unions are an essential part of the student organizations in higher institutions. As organizations established out of the interests and needs of the students themselves, student unions serve as bridges between school authorities and students and play a positive role in strengthening the campus culture, improving the educational environment, and promoting the overall development of the students. However, as China continues on the road to internationalization, current development of student unions cannot meet the growing requirement of social development and the goal to foster globally competitive talents. Universities in HMT shares similarities and relevance with those in mainland China and provide channels for universities in mainland China to learn from the West. Among worldwide universities, American student unions and university culture are one of the best. Therefore, we conducted research at universities outside mainland China including United States, Hong Kong, Macau and Taiwan and in Guangdong province including Jinan University, mainland China. We observed important differences in social background, values, economic development, and educational philosophy, which affect the way student unions are formed, organized and developed. On the basis of these differences and the current situation in higher education in mainland China, this article aims to analyze, compare and put forward proposals on the organization and administration of student unions.

\section{Current Situation of Student Unions Inside and Outside Mainland China}

\subsection{Student Unions Outside Mainland China}

In higher institutions outside of mainland China, student unions and organizations are collectively called student societies, which are created by students voluntarily for specific purposes. They are mainly comprised of student unions at university and faculty levels and are organizations where students have hobbies, academic interests, sports, and civic interests in common. There are also groups for other objectives such as communication and media. In some universities in the United States, students place great value and importance on student societies which, in turn, maintain diversity and proactivity among their members, bringing together members with solid academic foundations, passion, energy and leadership. For instance, in the University of Florida (UF), the student union is called the "Heart of the Campus", which is located at the center of the campus. The Labor Union offers them space to study, socialize, host events, attend meetings, and engage in campus life with members of 
the UF community. Most of the student societies at UF have their own individual website, which not only encourages the active participation of students, but also enables students to obtain new knowledge and develop personal skills. This is one of the successful elements in the American university model.

Taking the higher institutions in HMT as an example, as can be seen in Table 1, student unions in HMT share some similarities with those in the United States in having a large number of student organizations with different themes and objectives. Established in 1912, the Hong Kong University Students' Union (HKUSU) is a non-profit organization with more than 15,000 members. It was registered in 1949 as an economically, politically, and administratively independent student organization. The Union consists of 130 different sub-organizations covering sports, entertainment, academic interest, religion and social benefits. The University of Macau Students' Union (UMSU) is similar to HKUSU in having its unique administration regulations. It has 80 sub-organizations including student associations at faculty level, and entertainment and sports clubs. The National Taiwan University Student Association (NTUSA) is principally composed of student associations at faculty level, and has 86 sub-organizations, enabling students to pursue their interests and obtain hands-on experience.

Table 1. Some students' union in HMT

\begin{tabular}{cccccc}
\hline $\begin{array}{c}\text { Student } \\
\text { union }\end{array}$ & $\begin{array}{c}\text { University } \\
\text { foundation } \\
\text { (year) }\end{array}$ & $\begin{array}{c}\text { Student union } \\
\text { establishment } \\
\text { (year) }\end{array}$ & $\begin{array}{c}\text { Number of } \\
\text { sub-organizations }\end{array}$ & Aypes of sub-organizations & Aims \\
\hline HKUSU & 1910 & 1912 & 130 & $\begin{array}{c}\text { Faculty/Academic } \\
\text { Societies, Hall Students' } \\
\text { Associations, sports clubs, } \\
\text { cultural clubs, and } \\
\text { independent clubs }\end{array}$ & $\begin{array}{c}\text { To promote the } \\
\text { welfare of the } \\
\text { student body }\end{array}$ \\
UMSU & 1981 & 1993 & & $\begin{array}{c}\text { Faculty/academic societies, } \\
\text { entertainment clubs, and } \\
\text { sports clubs }\end{array}$ & $\begin{array}{c}\text { Humanity, } \\
\text { Integrity, } \\
\text { Propriety, } \\
\text { Wisdom and } \\
\text { Sincerity }\end{array}$ \\
NTUSA & 1928 & 1988 & 80 & Faculty societies & $\begin{array}{c}\text { To promote a } \\
\text { fairer NTU of } \\
\text { high-class }\end{array}$ \\
\hline
\end{tabular}

\subsection{Student Unions in Mainland China}

Table 2. Some student unions in Guangdong province

\begin{tabular}{cccccc}
\hline $\begin{array}{c}\text { Student } \\
\text { union }\end{array}$ & $\begin{array}{c}\text { University } \\
\text { foundation } \\
\text { (year) }\end{array}$ & $\begin{array}{c}\text { Student union } \\
\text { establishment } \\
\text { (year) }\end{array}$ & $\begin{array}{c}\text { Number of } \\
\text { sub-organizations }\end{array}$ & $\begin{array}{c}\text { Types of } \\
\text { sub-organizations }\end{array}$ & Aims \\
\hline $\begin{array}{c}\text { SYSU } \\
\text { Student } \\
\text { Union }\end{array}$ & 1924 & 1924 & $/$ & $\begin{array}{c}\text { Faculty/ campus } \\
\text { societies }\end{array}$ & $\begin{array}{c}\text { To share caring } \\
\text { for life and } \\
\text { promote personal } \\
\text { growth }\end{array}$ \\
$\begin{array}{c}\text { JNU } \\
\text { Student } \\
\text { Union } \\
\text { SCAU }\end{array}$ & 1906 & 1978 & $/$ & $\begin{array}{c}\text { Faculty/ campus } \\
\text { societies }\end{array}$ & $\begin{array}{c}\text { Unity, progress } \\
\text { and service to } \\
\text { JNU students }\end{array}$ \\
$\begin{array}{c}\text { Student } \\
\text { Union }\end{array}$ & 1909 & 1956 & $/$ & Faculty societies & To serve the \\
students
\end{tabular}

In Mainland China, there is a distinct difference between student association and student union. The student associations are formed voluntarily by the students themselves out of their interest and hobbies, and carry out activities according to the constitution of each organization; the establishment of a student union is coordinated by university party authorities and organized by university/faculty youth league committee. As can be seen in 
table 2, there is a noticeable difference in the number and diversity of student associations in Guangdong province in comparison with the organizations at universities outside of mainland China. Despite the difficulties that have arisen during the development of these organizations in Guangdong province, some important advances and successes they have achieved in promoting campus culture should be mentioned. For example, the student union at Jinan University (JNU) has consecutively organized a series of brand activities including the International Folk Dancing Contest, Chinese Culture Festival, and Overseas Chinese Students Cup, all of which have become popular among the students. South China Agricultural University (SCAU) organizes "A Date with the President", in which students can directly communicate with the school authorities and provide feedback regarding the issues students consider most important. Another successful example that has been recognized as a very insightful activity by many students, is the conference series organized by Sun Yat-Sen University (SYSU) "My growth and campus development: Stories from Sun Yat-Sen University alumni".

\section{Comparison of Organizational Construction of Student Unions Inside and Outside Mainland China}

\subsection{Committee Election}

The student unions in the United States are completely independent of the university administration, enjoying independent executive capacities, constitutions and autonomous organization. The election of the executive committee of the union is always a great annual event on campus, which generally takes place in spring to prepare the committee for the following school year. The executive committee is directly elected by all students and candidates are usually sophomores or seniors. The student unions in universities of Hong Kong have been legally registered as autonomous groupings by Hong Kong SAR Government and have organization, administrative, financial and operational independence. Although in practice, the coordination, administration and monitoring are still under the instruction of authorities from the student affairs office, the union committee in these universities are elected through voting in which all students of the university participate anonymously. Once the committee members are elected, they have the right to reorganize the structure of the student union. In the case of Taiwan, according to NTU Student Association Constitution, the president of the union is elected by direct student voting in May each year, and the rest of the representatives are elected in May and December.

Democratic centralism is practiced in student union elections in higher education in mainland China. Each faculty will first elect student representatives, who make up the student congress of the university. The president of the student union and other committee members will be elected by the student congress. In general, the president and vice-president of the union are nominated by the last committee and related departments and elected by the new student congress. The elected candidates will be examined by the university youth league committee and approved by the university party committee and Guangdong Students' Federation.

Table 3. Committee election of student unions inside and outside mainland China

\begin{tabular}{ccc}
\hline $\begin{array}{c}\text { University Election } \\
\text { process }\end{array}$ & $\begin{array}{c}\text { Candidates are nominated by related departments and } \\
\text { the last committee, and elected by student congress }\end{array}$ & $\begin{array}{c}\text { Polling by all students on a } \\
\text { voluntary basis }\end{array}$ \\
\hline $\begin{array}{c}\text { Universities in } \\
\text { mainland China }\end{array}$ & The communist youth league, student union, club & \\
$\begin{array}{c}\text { Universities outside } \\
\text { mainland China }\end{array}$ & $/$ & University student union \\
\hline
\end{tabular}

\subsection{Organization Structure}

There is a great diversity of student organizations in the United States, since students prefer to join autonomous organizations (also called student government) independent of university authorities. The student union is the most complete student organization in higher education in the United States with members from all campuses. Normally these autonomous student organizations have executive, legislative and judicial branches. Their structure, rights and responsibilities are stipulated by the constitution of the union. As student unions at universities in Hong Kong and Macau enjoy greater autonomy, they have greater financial and administrative flexibility. These organizations are usually formed by full-time undergraduate students and can be seen as the equivalent of a union consisting of the university student union and club associations in mainland China. HKUSU sets up a representative committee and an executive board. In addition, an arbitration committee is established to complete the three powers in the organization. UMSU establishes a general assembly, a board of directors, a supervisory board, and a presidium. The presidium consists of one president, one vice-president and one secretary, all of whom cannot hold a concurrent post in the affiliated organizations. NTUSA also has 
executive, legislative (student congress) and judicial (student court) powers. The committee is comprised of a president, a speaker, and student chief judge.

Student unions in mainland China are led by the president of the union and co-managed by a vice president or secretary. Each department of the union has a chief and chief assistants to complete functions of the department. The student congress holds the highest power in the organization and the presidium share collective responsibility. The student unions are additionally divided into university and faculty societies. Faculty societies are supported and coordinated by faculty party committees and youth league committees, as well as university student unions.

\subsection{Activities and Financial Sources}

Generally the student unions outside of mainland China already have more advanced and complete policies and regulations for their financial administration, and more funds are allocated for the organization of the union's activities. In the United States, the union funds are mainly raised from the registration fees paid by the students who want to participate in activities. Additionally some related university departments, foundations and alumni and community organizations also sponsor the union. Another fund raising method adopted by many universities, like Stanford University, is to create marketing and business opportunities; for example the student union independently runs restaurants and bookstores, organize events like movie festivals, organize group trips, and sell compendiums of important conferences or classes. Students' unions in Hong Kong are also independent in the organization, financial administration and operation of the union. They have their own office building, cooperative unit, printing center, shopping center and industrial businesses. These organizations have rich experience in publicity and decoration, and make use of business operational modes to increase their presence and reach, attracting attention to student organizations. Thanks to this effective model, alumni and other community associations and business also make donations to the students' union. In addition to the economic sources above, funds allocated by the university and the SAR government, together with the profits obtained from the businesses run by the students themselves, constitute the main financial sources of the union. With sufficient financial resources, student organizations out of mainland China can afford to organize more varied activities with attractive content, covering every aspect of campus life. These activities have become a reflection of the richness of university culture. The availability of resources is not only a great help in the organization of activities, but it also creates better conditions for members of the organization to obtain experience in project management.

Table 4. Comparison of financial sources of student unions inside and outside mainland China

\begin{tabular}{|c|c|c|c|c|c|}
\hline $\begin{array}{l}\text { Type of } \\
\text { institution }\end{array}$ & \multicolumn{5}{|c|}{ Financial sources } \\
\hline $\begin{array}{l}\text { Institutions in } \\
\text { mainland China }\end{array}$ & \multicolumn{5}{|c|}{$\begin{array}{l}\text { Mainly from university appropriation; student unions with certain influence can obtain } \\
\text { donations from the society. }\end{array}$} \\
\hline $\begin{array}{l}\text { Institutions } \\
\text { outside } \\
\text { mainland China }\end{array}$ & $\begin{array}{l}\text { Membership fees or } \\
\text { new student } \\
\text { registration fees }\end{array}$ & $\begin{array}{l}\text { University or } \\
\text { government } \\
\text { appropriation }\end{array}$ & $\begin{array}{l}\text { Donations } \\
\text { from the } \\
\text { society }\end{array}$ & $\begin{array}{c}\text { Revenues from } \\
\text { businesses run } \\
\text { by the union }\end{array}$ & $\begin{array}{c}\text { Participation fees } \\
\text { for some campus } \\
\text { activities }\end{array}$ \\
\hline
\end{tabular}

Unlike student unions outside mainland China, student organizations in mainland China have a smaller budget, which has been a constant obstacle in their development. Currently the student unions receive funds from two main sources: a budget allocated by the university and donations from enterprises. Because the organization of activities relies mainly on funds from the limited budget allocated by the university, the activities tend to be of smaller scale and have effects not as visible as those organized by student organizations outside of mainland China. In addition, student organizations also encounter problems with marketability, variety and creativity, and generating profits.

\subsection{Management and Development}

The advanced experience in administration adopted by student associations outside of mainland China can be used not only to boost the development of student organizations, but can also generate benefits for the university. In the United States, a series of administrative systems with high efficiency have been established, including annual inspection systems, activity reporting systems, and activity management systems. The American universities also have regulations for the administration of student associations, facilitating the organization and administration of associations while simultaneously promoting their sound and sustainable development. Student 
associations in Singapore are directed by the office of student affairs, and have established administration, participation and incentive system. In addition, Singaporean universities take advantage of digital information technologies, greatly increasing the efficiency of administrative work, even managing to do paperwork without spending paper. The student associations in the universities of Hong Kong and Macau in practice are under the instruction of student affair department with a focus on providing services to all students. Members of the associations have positions similar to jobs in companies or academic institutions, which resembles the administrative model of student societies in western developed countries.

Student associations in mainland China have already developed a system of regulations covering different administrative needs, such as the "Student Association Regulations", "Position Responsibilities in Student Associations" and "Regulations on Financial Management of Student Associations". However, there are still aspects of administration that are not regulated or follow relatively outdated methods, resulting in a notable difference in efficiency compared to student organizations in HMT and developed countries in the West. Another problem that currently exists in the universities of Mainland China is the lack of long-term plans for the development of different student associations. Many associations are created to cover a temporary interest and in many cases it becomes unsustainable after the recruitment of new students. In addition, student associations have few opportunities to conduct external communication, which limits the possibility of creating lasting and stable cooperative relationships with companies and other social organizations.

\section{Proposals for Strengthening Student Associations in Higher Education in Mainland China}

Through the analysis of different aspects regarding the culture and the creation and administration of student associations in higher education outside of mainland China, we can clearly see the distinctive characteristics of student organizations in mainland China and disparity between student societies inside and outside mainland China. There are some aspects that require attention and changes both in theory and in practice. Below are some aspects that can serve as a reference to promote the development of these organizations in the future.

\subsection{Strengthen the Administration of Associations, Improve Regulatory Systems and Ensure a Sustainable Development}

The development of student associations requires the establishment of a complete administration system, including the creation of regulations, administrative statutes, incentive systems, supervision, and member training. Higher institutions in mainland China should pay more attention to student organizations by providing guidance, selecting teachers with a high sense of responsibility, political awareness and technical ability to serve as counselor of associations, and constantly improving the work system so as to adapt to the demands that arise over time and ensure a sound and sustainable development of student organizations. Meanwhile, efforts should be made to arouse interest in students to participate in the design process, construction and administration so as to foster a democratic and self-governing atmosphere.

\subsection{Increase Economic Support and External Communication}

The high variety of activities organized in student associations outside mainland China is achieved due to the abundance of economic resources, which come in part from the universities and partly from the programs designed and operated by the students. Because material resources and space are limited in most universities in mainland China, results are strongly affected, which is why it is important that universities increase financial support to these organizations, from necessary expenses and space for activities to infrastructure construction for student organizations. In addition, higher institutions should motivate students to perform different social services so as to obtain resources and donations from companies and organizations. In this way, the external communication of student organizations with the society will also be strengthened and students will also gain hands-on experience that are not learned in classrooms.

\subsection{Strengthen the Identity of Organizations and Promote a Culture of Quality}

The activities organized by student associations are the main demonstration of their development, and creativity is one of the essential elements of this development. There are large amounts activities organized in higher institutions in mainland China but most of them are organized by the authority, resulting in poor student participation. Nowadays, higher institutions in mainland China should strive to promote active student participation in activities, and explore the creation of innovative activities that attract more students, and simultaneously draw the attention of social sectors. While regulating and establishing new standards in the operation and organization of student association activities, emphasis should be placed on maintaining the characteristics that make these activities attractive. Student organizations should absorb the best from diversity and establish a basic culture for themselves. Only in this way will student associations be able to develop 
comprehensively and foster a culture of quality among the students.

\subsection{Build Platforms for External Communication and Foster a Culture of Openness}

In order to meet the demands of the education of young students in the new social environment, higher institutions in mainland china have created different activities and platforms for communication with institutions outside of mainland China, such as HMT youth cultural tour, leadership camps for Guangdong and HMT students and summer camps for Chinese heritage students. With the development of administration and services to student association activities, there is a clear tendency toward more flexible models open to society in general. The detailed administration and openness in activities help expand the vision of the members, promoting comprehensive personal growth and fostering a social spirit of cooperation. In addition, higher institutions must actively explore different modes of international cooperation, which will reinforce the means of communication between members of different faculties in each institution, and allow the expansion and development of their organizations.

\section{References}

Ji, H. Q. (2010). An analysis on student work in Singaporean higher education. Modern Education Science, 1, 116-118.

Liao, L. H. (2005). A comparison of student association administration in Chinese and American higher education: take Harvard University as an example. Youth Studies, 4, 45-49.

Liu, Y. H., \& Liu, G.R. (2012). An analysis of student organization in higher education in Taiwan and mainland China. Higher Agricultural Education, 7, 93-95.

Yu, W., \& Han, L. Y. (2002). Comparative Research of Several Problems on the Culture Construction of Student Organization in the PRC and the USA. Studies In Foreign Education, 29(10), 57-60.

Zhu, F., Liu, W. \& Zhang, Q. (2008). The Present Conditions and Administrations of the University Student Organizations in Hong Kong: Inspiration for the Universities in Mainland China. Journal of Guangxi Youth Leaders College, 19(2), 26-28+31.

http://www.Harvard.edu.com

http://cn.nus.edu.sg

\section{Copyrights}

Copyright for this article is retained by the author(s), with first publication rights granted to the journal.

This is an open-access article distributed under the terms and conditions of the Creative Commons Attribution license (http://creativecommons.org/licenses/by/4.0/). 